\title{
Different Expressions of AQP1 and AQP4 in Hyponatremic Rat Brain
}

\author{
Diferentes Expresiones de AQP1 y AQP4 en Cerebro de Rata Hiponatrémico
}

\author{
Jun Hyeuck Lim'; Yong Wook Jung ${ }^{2} \&$ Hyo Seok Park ${ }^{1}$
}

LIM, J. H.; JUNG, Y. W. \& PARK, H. S. Different expressions of AQP1 and AQP4 in hyponatremic rat brain. Int. J. Morphol., 39(1):64-69, 2021.

SUMMARY: The expression of aquaporin-1 (AQP1) in choroid plexus and aquaporin-4 (AQP4) in astrocyte of the hippocampal formation (HF) was studied in the rat to determine the role of AQP1 and AQP4 in the pathophysiology of systemic hyponatremia (SH). SH was induced by coadministration of dextrose solution intraperitoneally and through subcutaneous implantation of an osmotic minipump containing 8 -deamino-arginin vasopressin $(50 \mathrm{ng} / \mu \mathrm{l} / \mathrm{h})$ for 24 and $48 \mathrm{~h}$. Twenty- four and $48 \mathrm{~h}$ after the drug administration, there were significant reductions in $\mathrm{Na}+$ concentration $(111 \pm 5$ and $104 \pm 2 \mathrm{mmol})$ and serum osmolarity $(240 \pm 13$ and $221 \pm 14 \mathrm{mOsm} / \mathrm{L})$ as compared with control values (140 $\pm 4.7 \mathrm{mmol}$ and $296 \pm 5.2 \mathrm{mOsm} / \mathrm{L}),(\mathrm{p}<0.01)$. The expression of AQP1 in the choroid plexus was increased three to five times from $24 \mathrm{~h}$ to 48 $\mathrm{h}$ after $\mathrm{SH}(329.86 \pm 10.2 \%$ and $531.5 \pm 4.4 \%, \mathrm{n}=4, \mathrm{p}<0.01)$. In contrast, AQP4 expression was significantly decreased up to $48 \mathrm{~h}$ after $\mathrm{SH}(36$ $\pm 9 \%, \mathrm{n}=4, \mathrm{p}<0.01$ ). Quantitative immunoblotting revealed significant decreases of neuronal proteins in the HF after 24 to $48 \mathrm{~h}$ of SH. Therefore, we suggest that altered expression of AQP1 and AQP4 plays important role in the pathogenesis of systemic hyponatremia.

KEY WORDS: Aquaporin-1; Aquaporin-4; Systemic hyponatremia; Cell death.

\section{INTRODUCTION}

Abnormality in brain water balance plays an important role in the pathophysiology of traumatic brain injury, stroke, and a variety of neurological disorders (Fishman, 1975). Systemic hyponatremia is the most common cause of abnormal increases in water content in the brain, termed brain edema. This can occur when a reduction in plasma sodium concentration produces an osmotic gradient promoting the movement of water from plasma into the brain. Because of restricted space within the cranium, serious consequences of brain water accumulation can include an increment of intracranial pressure (ICP) and the subsequent impairment of cerebral perfusion by vascular compression, leading to brain ischemia, herniation, and death (Strange, 1992). However, the molecular mechanism underlying the regulation of brain water content during systemic hyponatremia remains poorly understood. Recently, however, membrane water channel aquaporins (AQPs) have been implicated in the pathophysiology of osmotically-driven brain edema during systemic hyponatremia at the molecular level (Papadopoulos et al., 2004).
The cerebrospinal fluid (CSF), a major extracellular fluid (ECF) compartment of the brain, is mainly produced by the choroid plexus of ventricular system in the brain (Spector \& Johanson, 1989). The choroid plexus is a branched structure made up of a single layer of epithelial cells and fenestrated blood capillaries, unlike those in the blood-brain barrier (BBB). Aquaporin-1 (AQP1) has been suggested to play an important role in CSF formation since AQP1 is selectively expressed in the apical surface of choroid plexus epithelium (Nielsen et al., 1993). Recently, it has been directly demonstrated that AQP1 is the main pathway for water transport and CSF secretion (Hasegawa et al., 1994). Aquaporin-1 deletion in mice reduced the osmotic water permeability of the choroid plexus and the production of CSF (Oshio et al., 2005). In contrast, CSF production was markedly increased during systemic hyponatremia and hyposmotic plasma dilution (Melton \& Nattie, 1984). Furthermore, systemic hyponatremia increased ICP (Melton \& Nattie), whereas an AQP1 deletion decreased it (Oshio et al.). These results strongly suggest that AQP1 expression may regulate ICP through the rate of

\footnotetext{
${ }^{1}$ Department of Anatomy DaeJeon University College of Korean Medicine 62 Daehak-ro, Dong-gu, Daejeon 34520 , Republic of Korea.

${ }^{2}$ Department of Anatomy, College of Medicine, Dongguk University, Gyeongiu 780-714, Republic of Korea.

Jun Hyeuck Lim and Yong Wook Jung have contributed equally to this work.

This research was supported by the Daejeon University Research Grants (2017).
} 
CSF production. However, it is unknown whether AQP1 expression in the choroid plexus epithelium can be altered under hyposmotic stress as demonstrated in systemic hyponatremia.

In the central nervous system (CNS), the BBB is composed of the capillary endothelium, basement membrane, and numerous astrocytic foot processes, and effectively separates the plasma from the extracellular space. Aquaporin4 (AQP4) is expressed in astrocyte foot processes near blood vessels in the rat (Nielsen et al., 1997) and human (Saadoun et al., 2002) brain, as well as in ependymal and pial surfaces in contact with CSF (Frigeri et al., 1995). This localization suggests that AQP4 plays a critical role in brain water balance. Recently, an AQP4 deletion protected mice from brain swelling in studies of water intoxication and permanent focal cerebral ischemia (Manley et al., 2000). However, Papadopoulos et al. described that an AQP4 deletion increased brain swelling in cases of intraperitoneal fluid infusion, focal freeze injury, and brain tumor.

The present study was designed to explore the possible role of the AQP1 and AQP4 expression in the pathophysiology of systemic hyponatremia using an experimental hyponatremic rat model. Quantitative immunoblot analysis was used to measure the expression level of AQP1 and AQP4 in the third ventricle choroid plexus and HF.

\section{MATERIAL AND METHOD}

Experimental animals. The studies were performed on 16 adult Spraque-Dawley rats initially weighing $270 \pm 8 \mathrm{~g}$. The rats were maintained on a standard rodent diet with free access to water. The experimental procedures used were reviewed and approved by the Animal Care and Use Committee of Daejeon University. Animal care and use were in accordance with the guidelines of the National Institutes of Health (Bethesda, MD). Before subcutaneous implantation of osmotic minipumps in the neck regions, rats were anesthetized with isoflurane. Osmotic minipumps (model 2001; Alzet, Palo Alto, CA) were prepared and equilibrated in saline for at least $4 \mathrm{~h}$ at 37 degrees prior to implantation.

Induction of systemic hyponatremia. Systemic hyponatremia was induced by simultaneous water loading (140mmol/l dextrose solution) and implantation with osmotic minipumps containing 8-deamino-arginin vasopressin (dDAVP) in saline and DMSO (30\%v/v) for 24 and $48 \mathrm{~h}$ as follows: 24 h group: $30 \mathrm{ml}$ ( $\sim 12 \%$ body weight) dextrose solution i.p. and $50 \mathrm{ng} / \mu \mathrm{l} / \mathrm{h}$ dDAVPs.c., followed by repeated doses of $20 \mathrm{ml}(\sim 8 \% \mathrm{BW})$ dextrose i.p. at $4 \mathrm{~h}$ after initiating the administration; $48 \mathrm{~h}$ group: $30 \mathrm{ml}(\sim 12 \% \mathrm{BW})$ dextrose solution solutioni.p. and $50 \mathrm{ng} / \mu \mathrm{l} / \mathrm{h}$ dDAVPs.c., followed by repeated doses of $20 \mathrm{ml}(\sim 8 \% \mathrm{BW})$ dextrose i.p. at 4 and $24 \mathrm{~h}$ after initiating the administration. Animals were sacrificed 24 $\mathrm{h}$ and $48 \mathrm{~h}$ after the first injection (Fig. 1). After completing the hydration protocols, rats were anesthetized with isoflurane, venous blood was taken for assessment of serum osmolarity and sodium concentration, and the brain was removed.

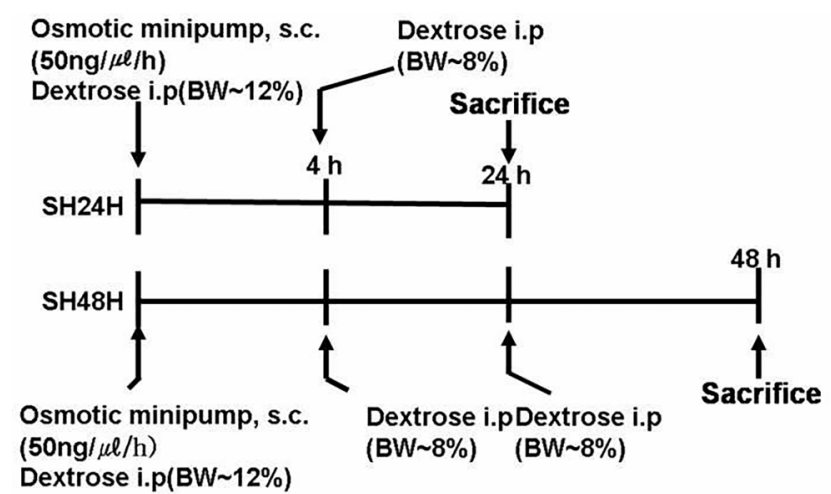

Fig. 1. Hydration protocol for induction of systemic hyponatremia in rats. Systemic hyponatremia was induced by simultaneous water loading (140mmol/l dextrose solution) and implantation with osmotic minipumps containing 8-deamino-arginin vasopressin (dDAVP) in saline and DMSO $(30 \% \mathrm{v} / \mathrm{v})$ for 24 and $48 \mathrm{~h}$ as follows: 24 h group: $30 \mathrm{ml}$ ( $\sim 12 \%$ body weight $)$ dextrose solution i.p. and $50 \mathrm{ng} / \mu \mathrm{l} / \mathrm{h}$ dDAVPs.c., followed by repeated doses of $20 \mathrm{ml}(\sim 8 \%$ BW) dextrose i.p. at $4 \mathrm{~h}$ after initiating the administration; $48 \mathrm{~h}$ group: 30ml ( 12\% BW) dextrose solution solutioni.p.and 50ng/ $\mu \mathrm{l} / \mathrm{h}$ dDAVPs.c., followed by repeated doses of $20 \mathrm{ml}(\sim 8 \% \mathrm{BW})$ dextrose i.p. at 4 and $24 \mathrm{~h}$ after initiating the administration.

SDS-PAGE and Immunoblotting. A homogenate of control $(n=4)$ and systemic hyponatremic rats $(n=4)$ was prepared by homogenizing the choroid plexus and hippocampal formation (HF) in ten volumes of homogenizing buffer $(0.32 \mathrm{mmol}$ sucrose, $25 \mathrm{mmol}$ imidazole, 1mmol EDTA, pH 7.2 containing $8.5 \mathrm{mmol}$ leupeptin, $1 \mathrm{mmol}$ phenylmethylsulfonyl fluoride), for $10 \mathrm{~s}$ with a polytron. Aliquots were stored at - 70 degrees.

Samples of homogenate were run on $9 \%$ 15\% polyacrylamide minigels (Bio-rad Mini Protean II). For each gel, an identical gel was run in parallel and subjected to Coomassie (Coomassie brilliant blue 0.3 g, 2-propanol 200 $\mathrm{ml}$, acetic acid $80 \mathrm{ml}, \mathrm{H}_{2} \mathrm{O} 640 \mathrm{ml}$ ) staining to assure identical loading. The other gel was subjected to immunoblotting.

After electrophoresis, the protein was transferred to nitrocellulose paper for 2 hours at $400 \mathrm{~mA}, 120 \mathrm{~V}$ in a BioRad trans-blot system using a buffer containing $50 \mathrm{mmol}$ Tris-base, $380 \mathrm{mmol}$ glycine, $20 \%$ methanol. After transfer, protein bands were identified by Ponceau S $(0.1 \%(\mathrm{w} / \mathrm{v})$ 
Ponceau S, $0.1 \%$ acetic acid) and destained with distilled water. Nitrocelluse sheets were washed 4 times (10 min each) in PBST (80 mmol NaH2PO4, $20 \mathrm{mmol} \mathrm{NaH} 2 \mathrm{PO} 4,100 \mathrm{mmol}$ $\mathrm{NaCl}, 0.1 \%$ Tween-20, pH7.5) and incubated with rabbit antirat AQP1- and AQP4- affinity purified polyclonal antibodies (Chemicon, Temecula CA, 1: 18,000, 1:500, respectively), as well as mouse anti- neuronal nuclei $(\mathrm{NeuN})$ and anti-glial fibrillary acidic protein (GFAP) monoclonal antibodies (Chemicon, Temecula CA, 1: 1,000, Boehringer Mannheim Biochemica, Philadelphia, USA, 1:2000, respectively) overnight at 4 degrees and then washed 2 times ( 10 min each) in PBST. The labeling was visualized with horseradish peroxidase (HRP)-conjugated secondary antibodies (DAKO, P448; Santa Cruz Biotechnology, SC 2031, 1:3,000) with an enhanced chemiluminescence (ECL) system (Amersham Pharmacia Biotech, Little Chalfont, UK). The resulting immunoblot signals were quantified using Scion Image software (version 1.59). Values are presented as means \pm SE. Comparisons between groups were made by unpaired t-test. P-values $<0.01$ were considered significant.

\section{RESULTS}

SDS-PAGE and Immunoblotting. The average serum $\mathrm{Na}+$ concentration was $140 \pm 5 \mathrm{mmol}(\mathrm{n}=4)$ in normonatremic controls and $111 \pm 5 \mathrm{mmol}(\mathrm{n}=4)$ and 104 $\pm 2 \mathrm{mmol}(\mathrm{n}=4)$ after 24 and $48 \mathrm{~h}$ of systemic hyponatremia, respectively. In addition, the serum osmolarity was significantly reduced from $296 \pm 5 \mathrm{mOsm} / \mathrm{L}$ (normonatremic control) to $240 \pm 13$ and $221 \pm 14 \mathrm{mOsm} /$ $\mathrm{L}$ (hyponatremic rats) after 24 and $48 \mathrm{~h}$ of systemic hyponatremia, respectively (Table I). Thus, a notable reduction in intravascular osmolality is able to promote water transport from the plasma into the brain, presumably leading to brain edema.

Table I. Serum ssmolality and sodium concentration at the end of the systemic hyponatremia.

\begin{tabular}{ccc}
\hline Group & $\begin{array}{c}\text { Serum Osmolarity } \\
(\mathrm{mOsm} / \mathrm{L})\end{array}$ & $\begin{array}{c}\text { Serum Sodium } \\
(\mathrm{mM} / \mathrm{L})\end{array}$ \\
\hline Control & $296 \pm 5$ & $140 \pm 4$ \\
24h hyponatremia & $240 \pm 13$ & $111 \pm 5$ \\
48h hyponatremia & $221 \pm 14$ & $104 \pm 2$ \\
\hline
\end{tabular}

Number: Mean \pm SE

Effect of systemic hyponatremia on AQP1 and AQP4 expression. The expression of AQP1 in the third ventricle choroid plexus epithelium was determined using a quantitative immunoblot analysis before and after the onset of systemic hyponatremia. Immunoblotting for AQP1 revealed a weak band of $28 \mathrm{kDa}$ and a major strong band of 35-50 kDa (Fig. 2A), representing deglycosylated and glycosylated isoforms of AQP1, respectively. Combined densitometric analyses of deglycosylated and glycosylated

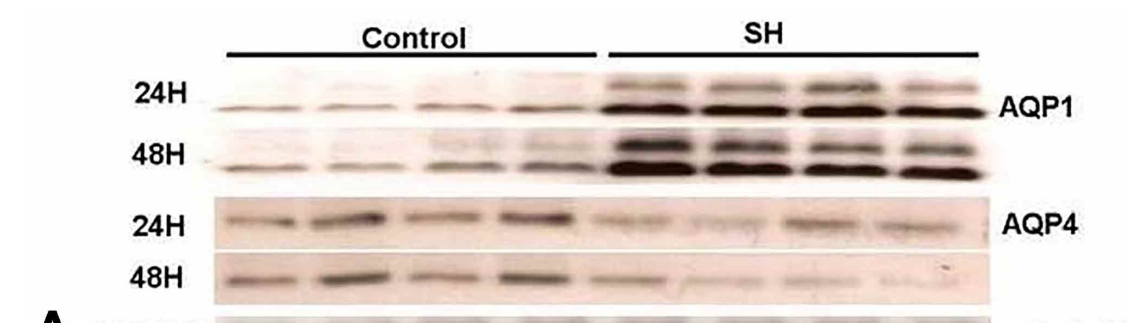

$\mathrm{A}_{55-65 \mathrm{kDa}}$

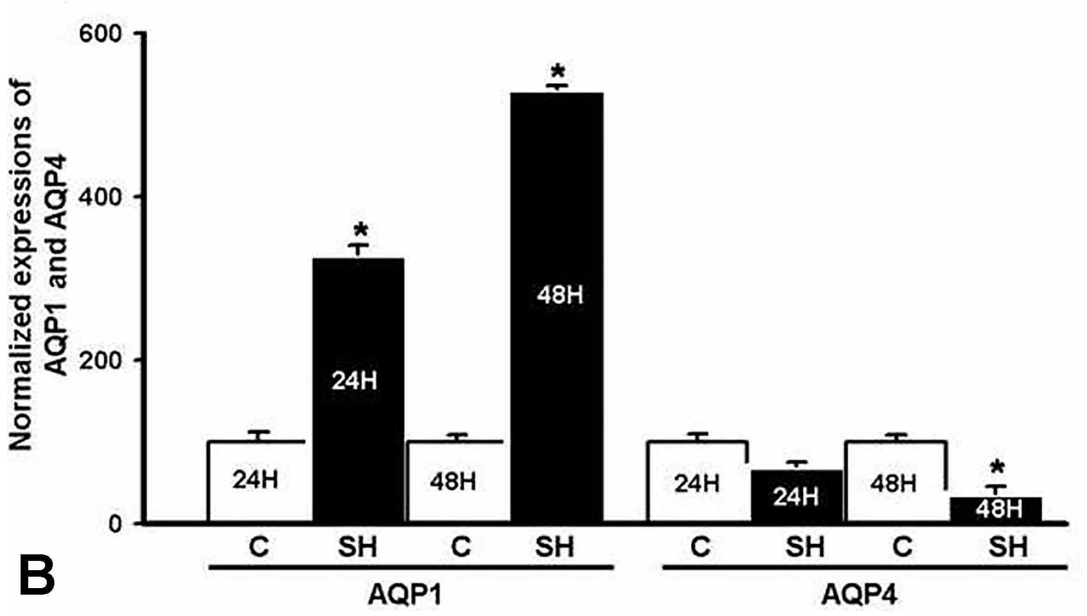

Fig. 2. A: Immunoblot with an antiaquaporin- (AQP1) antibody revealed two bands of AQP1, $28 \mathrm{kDa}$ and 30-50 kDa, representing deglycosylated and glycosylated forms of AQP1, respectively. Immunoblots were reacted with affinity purified anti-AQP4 antibody and revealed a $32 \mathrm{kDa}$ product. B: Normalized expressions of AQP1 proteins determined by combined densitometric analyses of the two isoforms of AQP1 protein. AQP1 expression was increased by $329.86 \pm 10.2$ $\%(\mathrm{n}=4, \mathrm{p}<0.01)$ after $24 \mathrm{~h}$ of systemic hyponatremia $(\mathrm{SH})$. The expression of AQP1 after $6 \mathrm{~h}$ of $\mathrm{SH}$ was maximally increased to $531.5 \pm 4.4 \%(\mathrm{n}=4, \mathrm{p}<0.01)$. In contrast, $\mathrm{SH}$ produced a decrease in AQP4 expression in the HF after $24 \mathrm{~h}$ (70 $\pm 5 \%$ of control). $48 \mathrm{~h}$ after $\mathrm{SH}$, the expression level of AQP4was maximally decreased $(36 \% \pm 9 \%$ of controls, $n=4$, $\mathrm{p}<0.01)$ compared with that of the controls. Error bars indicate s.e.m. $* \mathrm{p}<0.01$ vs control. 
AQP1 isoforms revealed that normalized AQP1 expression was significantly increased by $329.86 \pm 10.2 \%(\mathrm{n}=4$, $\mathrm{p}<0.01)$ and $531.5 \pm 4.4 \%(\mathrm{n}=4, \mathrm{p}<0.01)$ after 24 and $48 \mathrm{~h}$ of systemic hyponatremia (Fig. 2B). These results directly demonstrate that systemic hyponatremia up-regulates AQP1 protein expression in the choroid plexus epithelium.

To quantitatively evaluate the effect of systemic hyponatremia on AQP4 expression in brain tissues, immunoblotting analysis using an affinity purified antiAQP4 antibody was performed on HF samples from experimental hyponatremic rats. In all hyponateremic rats, immunoblotting for AQP4 revealed a major strong band at $32 \mathrm{kDa}$ (Fig. 2A). In contrast with AQP1 expression, densitometric analyses on the expression levels of AQP4 showed that the AQP4 expression level was decreased 24 $h$ after the onset of systemic hyponatremia $(70 \pm 5 \%$ of control). In addition, $48 \mathrm{~h}$ after systemic hyponatremia, the expression level of AQP4 was significantly decreased (36 $\% \pm 9 \%$ of controls, $\mathrm{n}=4, \mathrm{p}<0.01$ ) compared with that of the controls (Fig. 2B).

Altered expression of neuronal and astroglial cell proteins in HF following systemic hyponatremia. Immunoblotting analyses demonstrated that the expression of neural (NeuN) and astroglial cell proteins (GFAP) was affected in the $\mathrm{HF}$ at 24 and $48 \mathrm{~h}$ after the systemic hyponatremia. Immunoblottings for NeuN and GFAP revealed a strong band at $46-48$ and $50 \mathrm{kDa}$ (Fig. 3A). The expression of NeuN (58 $\pm 6 \%$ of controls; $23 \pm 4 \%$ of controls, $\mathrm{p}<0.01)$ and of GFAP ( $45 \pm 4 \%$ of controls; $20 \pm$ $4 \%$ of controls, $\mathrm{p}<0.01$ ) was significantly decreased in the HF 24 and $48 \mathrm{~h}$ after systemic hyponatremia (Fig. 3B). The decrease of GFAP after systemic hyponatremia was more prominent than that of NeuN.

\section{DISCUSSION}

Increase of AQP1 expression in choroid plexus 24 to $48 \mathrm{~h}$ post-ponatremia. Expression of the AQP1 protein in the choroid plexus epithelium was significantly increased by $329 \%$ and $531 \%$ after 24 and 48 h of systemic hypoatremia, respectively. These findings indicate that the osmotic water permeability of the blood-CSF barrier was significantly increased in response to systemic hyponatremia. In support of this, it has been demonstrated that, in AQP1 null mice, the osmotic water permeability across the choroidal epithelium was reduced by fivefold and simultaneously there was a $25 \%$ reduction in CSF production (Oshio et al.). Thus, it is reasonable that the overexpression of choroidal AQP1 water channels could result in CSF overproduction.
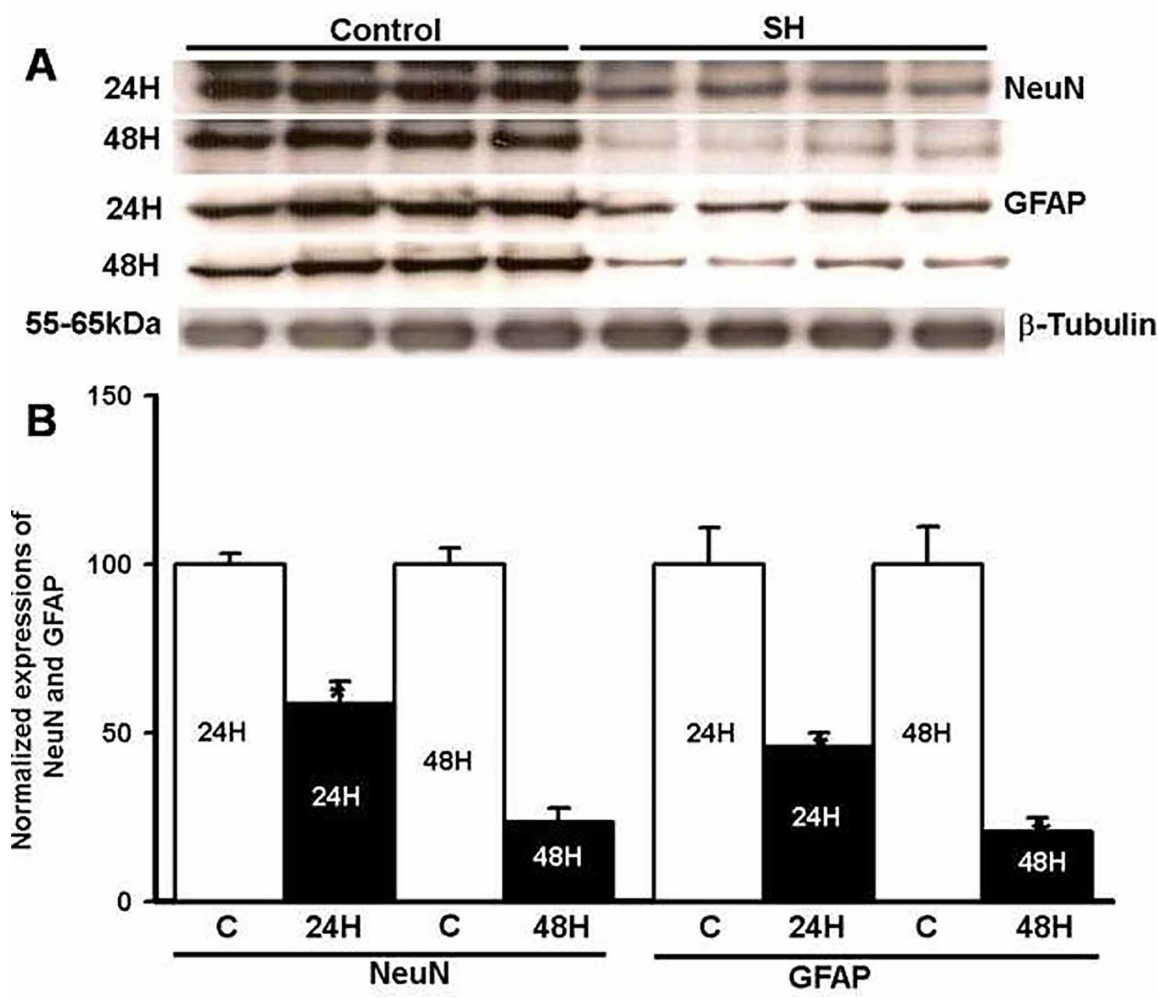

Fig. 3. Expression of neuronal nuclei $(\mathrm{NeuN})$ and glial fibrillary acidic protein (GFAP) in rats with control and systemic hyponatremic rats. A: Immunoblot was reacted with affinity purified anti- NeuN and anti-GFAP antibodies and revealed 46-48 and $50 \mathrm{KDa}$ bands in control and hyponatremic hippocampal formation (HF). B: Densitometric analysis revealed that $\mathrm{SH}$ produced a significant decrease in NeuN and GFAP expression in $\mathrm{HF}$

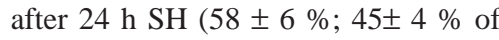
control) and $48 \mathrm{~h} \mathrm{SH}(23 \pm 4 \% ; 20 \pm 4$ $\%$ of control). Error bars indicate s.e.m, $* \mathrm{p}<0.01$ vs control. 
Previous studies have noted that systemic hyponatremia leads to a marked increase in the rate of CSF production: a $1 \%$ decrease in plasma osmorality resulting in a $6.7 \%$ increase in CSF production (Hochwald et al., 1974). If this is correct, a $26.6 \%$ reduction in plasma osmorality would result in an increased in CSF production of approximately $178.2 \%$. However, there are also studies suggesting that the choroid plexus may account for only 25 $50 \%$ of the total CSF production and that extracellular CSF production could be significant. Choroid plexotomy has also been demonstrated to reduce CSF production by $30-50 \%$ in rhesus monkeys and in dogs (Milhorat et al., 1971). Recently, a deletion of AQP1 in mice reduced CSF production by 25 $\%$ (Oshio et al.). Thus, it can be expected that the maximal $531 \%$ increase in AQP1 expression during systemic hyponatremia could result an increase in total CSF production of approximately $44.5 \%$. Additionally, there is evidence that AQP1 expression is regulated by plasma osmolality. Following from this, the AQP1 promoter within the AQP1 gene contains a hypertonicity-response element (Umenishi \& Schrier, 2003) and hypertonicity has been shown to increase AQP1 expression in peritoneal tissues (Ota et al., 2002) and in cultured mouse medullary (mIMCD-3) cells (Strange). However, it is unknown whether the expression of AQP1 in the choroid plexus can be regulated by plasma osmolality.

Decrease of AQP4 expression in HF 24 to $48 \mathrm{~h}$ posthyponatremia. Aquaporin- 4 is expressed in the dense astrocyte cell processes that form the BBB and glia limitans, a structure that lines the pial and ependymal surfaces in contact with the CSF in the subarachnoid space and the ventricular system (Frigeri et al.; Nielsen et al., 1997). It is not, however, expressed by neurons or meninges (Frigeri et al.). This suggests that $\mathrm{AQP} 4$ is concentrated at the perivascular membrane of astrocytes where it is involved in the movement of water between blood and brain compartments.

Our results demonstrate a progressive fall in serum osmolality from 296 to 240 and $221 \mathrm{mOsm} / \mathrm{L} 24$ and $48 \mathrm{~h}$ post-hyponatremia, producing an osmotic gradient driving water entry into the brain. However, our results also revealed that systemic hyponatremia 24 and $48 \mathrm{~h}$ post- hyponatremia produced a $30 \%$ and $64 \%$ decrease in AQP4 expression. Perhaps this can be explained by recent reports indicating that decreased expression of AQP4 may reflect an endogenous protective mechanism reducing further glial water accumulation and thereby counteracting evolving cell swelling in rats after either traumatic brain injuryor hyponatremia combined with brain contusion (Ke et al., 2002). In contrast, Papadopoulos \& Verkman (2007) reported that an AQP4 deletion aggravates vasogenic brain edema produced by tumors, cortical freezing, intraparenchymal fluid infusion, or brain abscess. These apposing actions of AQP4 in brain edema are probably related to the bi-directional water transport through the AQP4 channel (Amiry-Moghaddam et al., 2003).

Our data here suggest that altered expression of AQP1 and AQP4 may synergistically contribute to water accumulation in the brain through the enhancement of the rate of water inflow to the brain parenchyma and the slowing of the exit of brain water into the blood vessels, thus resulting in the acceleration of neural and glial cell death from 24 to 48 $\mathrm{h}$ after systemic hyponatremia.

Decreased neural and astroglial proteins in the HF after systemic hyponatremia. Systemic hyponatremia produced neural and astroglial cell death in the HF after 24 to $48 \mathrm{~h}$. The greatest level of cell death in the rat brain parenchyma, including the HF, seems to correspond to the maximal increase and decrease of AQP1 and AQP4 expression in the brain. These results support the theory that altered expressions of AQP1 and AQP4 play critical role in the pathogenesis of systemic hyponatremia.

Because the skull is a rigid structure, the total volume of the three major constituents, the brain, blood, and CSF, must remain nearly constant. An increase in the volume of CSF and other brain constituents, as a result of systemic hyponatremia, will therefore result in increased ICP. An elevation of ICP may lead to a marked compression of the capillaries and small venules in the brain, thereby accelerating cell death by inducing an ischemic state as well as brain swelling.

Prominent glial cell death compared with that of neurons after systemic hyponatremia. The present data demonstrate that astrogial proteins are more severely decreased than those of neurons after systemic hyponatremia. In general, astroglias are highly sensitive to changes in extracellular osmolarity, and it has been demonstrated that decreases in external osmolarity induce transient rapid swelling in glial cells (Pasantes-Morales et al., 2000). Studies in cultured astrocytes document the efflux of taurine, GABA, glutamate, and glycine in response to hypoosmotic stimuli (Pasantes-Morales, 1993). Therefore, astroglia are likely to be more susceptible that neurons to changes in extracellular osmlarity after systemic hyponatremia. The predominant death of glial cells in brain edema may result in the release glia intracellular contents into the extracellular space (Kimelberg, 1995). In addition, decreased neuronal survival is inextricably linked to impaired glial function including the modulation of neuronal excitability (Ransom \& Sontheimer, 1992), the regulation of extracellular ion concentrations (Kempski et al., 1991), and the uptake of neurotransmitters (Westergaard et al., 1995) after systemic hyponatremia. 


\section{ACKNOWLEDGEMENTS}

This research was supported by the Daejeon University Research Grants (2017)

LIM, J. H.; JUNG, Y. W. \& PARK, H. S. Diferentes expresiones de AQP1 y AQP4 en cerebro de rata hiponatrémico. Int. J. Morphol., 39(1):64-69, 2021.

RESUMEN: En este análisis se estudió la expresión de acuaporina-1 (AQP1) en plexo coroideo y acuaporina-4 (AQP4) en astrocitos de la formación hipocampal (FH) en ratas para determinar el papel de AQP1 y AQP4 en la fisiopatología de la hiponatremia sistémica (HS). La HS fue inducida mediante la coadministración de solución de dextrosa por vía intraperitoneal y mediante la implantación subcutánea de una minibomba osmótica que contenía vasopresina 8-desaminoarginina ( $50 \mathrm{ng} / \mu \mathrm{l} / \mathrm{h}$ ) durante $24 \mathrm{y} 48 \mathrm{~h}$. Veinticuatro y 48 h después de la administración del fármaco, hubo reducciones significativas en la concentración de $\mathrm{Na}+(111 \pm 5$ y $104 \pm 2 \mathrm{mmol})$ y la osmolaridad sérica $(240 \pm 13$ y $221 \pm 14 \mathrm{mOsm} / \mu \mathrm{L})$ en comparación con los valores de control ( $140 \pm 4,7 \mathrm{mmol}$ y $296 \pm 5,2 \mathrm{mOsm} / \mathrm{L}$ ), (p $<0,01)$. La expresión de AQP1 en el plexo coroideo se incrementó de tres a cinco veces de 24 a 48 h después de HS $(329,86 \pm 10,2 \%$ y $531,5 \pm 4,4 \%, \mathrm{n}=4, \mathrm{p}<0,01)$. Por el contrario, la expresión de AQP4 se redujo significativamente hasta $48 \mathrm{~h}$ después de HS $(36 \pm 9 \%, \mathrm{n}=$ 4 , p <0,01). La inmunotransferencia cuantitativa reveló disminuciones significativas de proteínas neuronales en el FH después de 24 a $48 \mathrm{~h}$ de SH. Por lo tanto, sugerimos que la expresión alterada de AQP1 y AQP4 juega un papel importante en la patogénesis de la hiponatremia sistémica.

PALABRAS CLAVE: Aquaporin-1; Acuaporina-4; Hiponatremia sistémica; Muerte celular.

\section{REFERENCES}

Amiry-Moghaddam, M.; Otsuka, T.; Hurn, P. D.; Traystman, R. J.; Haug, F. M.; Froehner, S. C.; Adams, M. E.; Neely, J. D, Agre, P.; Ottersen, O. P. \& Bhardwaj, A. An alpha-syntrophin-dependent pool of AQP4 in astroglial endfeet confers bidirectional water flow between blood and brain. Proc. Natl. Acad. Sci. U. S. A., 100(4):2106-11, 2003.

Fishman, R. A. Brain edema. N. Engl. J. Med., 293(14):706-11, 1975.

Frigeri, A.; Gropper, M. A.; Umenishi, F.; Kawashima, M.; Brown, D. \& Verkman, A. S. Localization of MIWC and GLIP water channel homologs in neuromuscular, epithelial and glandular tissues. J. Cell Sci., 108(Pt. 9):29933002, 1995.

Hasegawa, H.; Ma, T.; Skach, W.; Matthay, M. A. \& Verkman, A. S. Molecular cloning of a mercurial-insensitive water channel expressed in selected watertransporting tissues. J. Biol. Chem., 269(8):5497-500, 1994.

Hochwald, G. M.; Wald, A.; DiMattio, J. \& Malhan, C. The effects of serum osmolarity on cerebrospinal fluid volume flow. Life Sci., 15(7):1309-16, 1974.

Ke, C.; Poon, W. S.; Ng, H. K.; Lai, F. M. M.; Tang, N. L. S. \& Pang, J. C. S. Impact of experimental acute hyponatremia on severe traumatic brain injury in rats: influences on injuries, permeability of blood-brain barrier, ultrastructural features, and aquaporin-4 expression. Exp. Neurol., 178(2):194206, 2002.

Kempski, O.; von Rosen, S.; Weigt, H.; Staub, F.; Peters, J. \& Baethmann, A. Glial ion transport and volume control. Ann. N. Y. Acad. Sci., 633:306-17, 1991.
Kimelberg, H. K.; Current concepts of brain edema. Review of laboratory investigations. J. Neurosurg., 83(6):1051-9, 1995.

Manley, G. T.; Fujimura, M.; Ma, T.; Noshita, N.; Filiz, F.; Bollen, A. W.; Chan, P. \& Verkman, A. S. Aquaporin-4 deletion in mice reduces brain edema after acute water intoxication and ischemic stroke. Nat. Med., 6(2):159-63, 2000.

Melton, J. E. \& Nattie, E. E. Intracranial volume adjustments and cerebrospinal fluid pressure in the osmotically swollen rat brain. Am. J. Physiol., 246(4 Pt. 2):R533-41, 1984.

Milhorat, T. H.; Hammock, M. K.; Fenstermacher, J. D. \& Levin, V. A. Cerebrospinal fluid production by the choroid plexus and brain. Science, 173(3994):330-2, 1971.

Nielsen, S.; Nagelhus, E. A.; Amiry-Moghaddam, M.; Bourque, C.; Agre, P. \& Ottersen, O. P. Specialized membrane domains for water transport in glial cells: high-resolution immunogold cytochemistry of aquaporin-4 in rat brain. J. Neurosci., 17(1):171-80, 1997.

Nielsen, S.; Smith, B. L.; Christensen, E. I. \& Agre, P. Distribution of the aquaporin CHIP in secretory and resorptive epithelia and capillary endothelia. Proc. Natl. Acad. Sci. U. S. A., 90(15):7275- 9, 1993.

Oshio, K.; Watanabe, H.; Song, Y.; Verkman, A. S. \& Manley, G. T. Reduced cerebrospinal fluid production and intracranial pressure in mice lacking choroid plexus water channel Aquaporin-1. FASEB J., 19(1):76-8, 2005.

Ota, T.; Kuwahara, M.; Fan, S.; Terada, Y.; Akiba, T.; Sasaki, S. \& Marumo, F. Expression of aquaporin-1 in the peritoneal tissues: localization and regulation by hyperosmolality. Perit. Dial. Int., 22(3):307-15, 2002.

Papadopoulos, M. C. \& Verkman, A. S. Aquaporin-4 and brain edema. Pediatr. Nephrol., 22(6):778-84, 2007.

Papadopoulos, M. C.; Manley, G. T.; Krishna, S. \& Verkman, A. S. Aquaporin-4 facilitates reabsorption of excess fluid in vasogenic brain edema. FASEB J., 18(11):1291-3, 2004.

Pasantes-Morales, H.; Alavez, S.; Sánchez Olera, R. \& Morán, J. Contribution of organic and inorganic osmolytes to volume regulation in rat brain cells in culture. Neurochem. Res., 18(4):445-52, 1993.

Pasantes-Morales, H.; Franco, R.; Torres-Marquez, M. E.; Hernández-Fonseca, K. \& Ortega, A. Amino acid osmolytes in regulatory volume decrease and isovolumetric regulation in brain cells: contribution and mechanisms. Cell. Physiol. Biochem., 10(5-6):361-70, 2000.

Ransom, B. R. \& Sontheimer, H. The neurophysiology of glial cells. J. Clin. Neurophysiol., 9(2):224-51, 1992.

Saadoun, S.; Papadopoulos, M. C.; Davies, D. C.; Krishna, S. \& Bell, B. A. Aquaporin-4 expression is increased in oedematous human brain tumours. $J$. Neurol. Neurosurg. Psychiatry, 72(2):262-5, 2002.

Spector, R. \& Johanson, C. E. The mammalian choroid plexus. Sci. Am., 261(5):6874, 1989.

Strange, K. Regulation of solute and water balance and cell volume in the central nervous system. J. Am. Soc. Nephrol., 3(1):12-27, 1992.

Umenishi, F. \& Schrier, R. W. Hypertonicity-induced aquaporin-1 (AQP1) expression is mediated by the activation of MAPK pathways and hypertonicity-responsive element in the AQP1 gene J. Biol. Chem., 278(18):15765-70, 2003.

Westergaard, N.; Sonnewald, U. \& Schousboe, A. Metabolic trafficking between neurons and astrocytes: the glutamate/glutamine cycle revisited. Dev. Neurosci., 17(4):203-11, 1995.

\section{Corresponding author \\ Hyo Seok Park \\ Department of Anatomy \\ DaeJeon University College of Korean Medicine \\ 62 Daehak-ro \\ Dong-gu \\ Daejeon 34520 \\ REPUBLIC OF KOREA}

Email: anatomy@dju.kr

Received: 13-08-2020

Accepted: 13-09-2020 